PUBLISHED AS: 2001 "Globalizing Resistance: The Battle of Seattle and the Future of Social Movements." Mobilization 6:1-20.

\title{
Globalizing Resistance:
}

\section{The Battle of Seattle and the Future of Social Movements ${ }^{1}$}

\author{
Jackie Smith \\ Department of Sociology \\ State University of New York at Stony Brook \\ Stony Brook, NY 11794-4356 \\ jackie.smith@sunysb.edu
}

${ }^{1}$ I am especially grateful to Patrick Gillham for his comments on several versions of this paper and for sharing some of his own research notes on the Seattle protests. Thanks also go to Joe Bandy, Betsi Beem, Pauline Cullen, Bob Edwards, John Gershman, Margaret Levi, John Markoff, David Maynard, Kelly Moore, Naomi Rosenthal, Sidney Tarrow, Charles Tilly, Lesley Wood, the Workshop on Contentious Politics at Columbia University, and to anonymous reviewers for their helpful feedback on previous versions of this paper. 


\begin{abstract}
The massive popular protests that disrupted the Third Ministerial Meeting of the World Trade Organization in November 1999 resulted from broad changes in global social and political relations that have accelerated in recent decades. Moreover, many of the groups involved in this protest event had been involved in previous struggles for global economic justice, and these past struggles contributed to the transnational identities and strategies that emerged in Seattle. This study examines the political context of the "Battle of Seattle," identifying the participants and activities that characterized the struggle. It explores the transnational linkages among activists, suggesting that a division of labor emerged in Seattle whereby groups with more local and national ties took on mobilization roles while groups with more routinized transnational ties served the role of providing information and frames for the struggle. An examination of the tactics used in Seattle suggests that, to a large extent, national protest "repertoires" have been adapted for use in global political arenas. However, there is some evidence of innovation in traditional protest forms in response to global political integration and technological innovations. While the study encompasses only a single protest event, the patterns it identifies suggest that globalization and the growing prevalence of transnational protest has had enduring impacts on the organization and character of social movements.
\end{abstract}

\title{
Globalizing Resistance:
}

\section{The Battle of Seattle and the Future of Social Movements}

On the evening of November 291999 Seattle business and political leaders hosted an elaborate welcoming party for delegates attending the World Trade Organization 's Third Ministerial Conference. At the same time, thousands of activists rallied at a downtown church in preparation for the first large, public confrontation in what became the "Battle of Seattle."2 Protesters emerging from the overflowing church joined many thousands more who waited, while variously dancing, chanting, and conversing, in a cold Seattle downpour to join the march. Marchers donning union jackets or rain ponchos that proclaimed their opposition to the World Trade Organization and celebrated the "Protest of the Century" filled several city blocks as they proceeded to the city ' s football stadium, the site of the WTO welcome party and the target of that

${ }^{2}$ During the weekend prior to the WTO meeting, a number of smaller street protests and other events took place, beginning on Friday afternoon with a regularly scheduled "Critical Mass" bicycle ride through the streets of downtown Seattle and an evening "teach-in" organized by the International Forum on Globalization. 
evening 's protest. An estimated 14,000 -30,000 marchers ${ }^{3}$ formed a "human chain " three or four people across that was to encircle the stadium and dramatize the crippling effects of the debt crisis on the economies of the global South. The protest deterred more than two thirds of the expected 5,000 guests from attending the lavish welcoming event. Although the human chain's symbolism of the "chains of debt" might have been lost on many delegates, the efforts of protesters supporting the international campaign to end third world debt ("Jubilee 2000") helped to highlight for some protesters and onlookers the enormous inequities of the global trading system as they kicked off a week of street protests and rallies against the global trade regime. ${ }^{4}$

The massive opposition to the World Trade Organization (WTO) during its Seattle meeting of Trade Ministers in late 1999 revealed a broad and diverse base of opposition to the expansion over recent decades of the neoliberal policies that have oriented the global economy. The "Battle of Seattle" and its predecessor campaigns against the Multilateral Agreement on Investment (MAI) and against "fast track" authorization in the U.S. represented some of the first major popular challenges to the neoliberal trajectory of global trade relations. Indeed, these campaigns may mark a crucial turning point in the direction of economic globalization by demonstrating a capacity for mass, grassroots challenges to international trade agreements that threaten popular concerns about human and labor rights and environmental protection. ${ }^{5}$

${ }^{3}$ Police estimates cited in local newspaper reports were 14,000; activists reported the estimate of $30,000(\mathrm{Njeh} \leftarrow 2000)$.

${ }_{4}$ This account and other details about the Seattle protest events are drawn from participant observation research which included: observation at Seattle marches and rallies, attendance at teach-ins, lectures, cultural events, press conferences, and strategy sessions organized by various factions of the anti-trade liberalization movement, informal interviews with participants; observation of the single pro-trade Seattle rally held by the local Christian Coalition chapter and the Chamber of Commerce, and analysis of organizational literature and electronic communications in addition to local, national, and some international media coverage. 5Evidence of the impact of the Seattle protests on at least the discourse of neoliberalism's advocates abounds. For instance, early in 2000, reports were released by the WTO, World Bank, IMF and OECD attempting to bolster the case that more trade is needed in order to address the needs of the world's poor. A report by the Canadian Security Intelligence Service (2000) noted the need for advanced security measures at international financial meetings. And the discourse at a meeting of the world's bankers and economists revealed elite attempts to respond to widespread "antipathy toward free market competition" (Stevenson 2000). 
Protests at the Third Ministerial meeting of the WTO in Seattle challenge traditional social movement theories ' accounts of state and social movement relationships as they demonstrate the increased salience of global-level politics for a wide range of local and national actors. We must ask how globalization-- or the global integration of economic, political and societal relations (both formal and informal) - affects both the ways that people mobilize and act in politics and social movements. First, in terms of mobilization, Seattle raises questions about the prospects for and limitations on social movement mobilization across national boundaries as well as across class and cultural divides. Critical analysts seek evidence about whether and how social movement actors can transcend local and national identities and interests in order to forge a coherent opposition to powerful state and corporate elites (see, e.g., Tarrow 2001; Fox 2000; Smith 2000).

Second, in terms of collective action, scholars must ask how global processes have affected opportunities for social movement actors that have forged their action repertoires through primarily nationally-oriented contention. Global integration has clearly altered traditional, state level politics and capacities. If inter-state relationships and treaties are becoming more important, then state decisions and practices are constrained to varying degrees by their relationships with other states and economic elites. How do global agreements alter domestic political opportunity structures? Moreover, how do differences in power and interests among states affect opportunities for challengers to exert leverage? To date, relations between social movements and inter-governmental organizations such as the United Nations have been largely accommodative, but Seattle highlights a more contentious history of relations between popular groups and inter-governmental financial institutions.

What does this contrast tell us about the nature of the contemporary global political system and of the role of social movements within it? This paper traces the origins and mobilizing structures behind the Seattle contention and analyzes the tactics of these protests and their relevance to international institutional contexts. By asking both who and what constituted the Battle of Seattle, this analysis seeks to advance understandings of how global integration 
impacts social movement mobilization and action.

\section{Background: The Seattle Ministerial}

The original WTO agreement passed in 1994 committed member states to pursue a Millennium Round of talks that would progressively expand trade liberalization policies under the WTO. The United States and other Western nations were strong advocates of a continued expansion of the WTO regime, and they made extensive efforts to advance these goals in the lead-up to the Seattle meeting. ${ }^{6}$ For many states in the global South, however, the WTO had proved to be a disappointment. Although attracted to the agreement by the promise of greater access to Western markets and greater influence on multilateral trade negotiations than they have in other global financial institutions, ${ }^{7}$ Southern governments found themselves left out of important decisions taken in the WTO as key deliberations were held in closed-door, "Green Room" meetings organized at the behest of the core states (the United States, Canada, European Union, and Japan, referred to as "the Quad"). Agreements defined in these secret meetings were then presented to Southern members who were most vulnerable to pressure from the powerful Quad states (Vidal 1999; Zoll 1999). Southern governments also realized fewer economic rewards from expanded trade under the WTO than they had expected. Their agenda in Seattle was therefore to review existing agreements and to make them more equitable rather than to support a Millennium Round whose agenda was to expand the WTO regime under rules they saw as highly skewed towards Western and corporate interests. ${ }^{8}$ This division among states was an

${ }^{6}$ Seeing that there was likely to be difficulty reaching an agreement on a Millennium Round, late in the lead-up to the Ministerial Conference President Clinton called upon heads of state to attend the meeting and show their support for WTO expansion. Only Fidel Castro signalled a willingness to take him up on the offer.

${ }^{7}$ Voting in the WTO provides one vote per country member, but in the IMF and World Bank it is weighted according to a government's financial contribution, and the U.S. enjoys the largest voting share (nearly $20 \%$ ).

${ }^{8}$ The WTO rules, for instance, progressively liberalize tariffs and other trade restrictions over a set period. Rules for different categories of goods vary, so that tariffs on primary commoditiesi.e., those that are exported from the South to the North- remain high until the end of the WTO phase-in period, while those on manufactured goods are reduced more rapidly. Moreover, most 
important cause of the ultimate breakdown of talks in Seattle. In addition to this North-South split among WTO member governments, a further challenge remained in divisions between European and U.S. interests over food safety and agricultural issues. In short, going into the Third Ministerial, governments faced difficult prospects for staging a successful meeting. All hope of bridging the North-South gap was effectively lost when President Clinton succumbed to pressure from protesters and pressed for labor protections within the WTO.

The social movement forces allied against the WTO expansion certainly contributed to this state of affairs. European governments felt pressures from constituent groups who had mobilized mass opposition to genetically modified foods and to trade rules that limited their ability to keep such products out of national food supplies. Farmers represent a strong constituency in many European countries, thereby complicating efforts to cut subsidies and other agricultural supports. Governments in the global South benefitted from analyses of the WTO provided by researchers who have served as intellectual leaders of the movement. 9 Moreover, their ability to present a cohesive challenge to the political dominance of the United States and other "Quad" states in the WTO was certainly bolstered by their knowledge that it was Quad governments' own citizens who were protesting the meetings. A more detailed counterfactual analysis would have a hard time making the case that the Seattle Ministerial would have failed as miserably as it did without the tens of thousands of protesters surrounding the meeting site.

The major slogan of the protests was "no WTO" (or "hell no, WTO" if you were a steel worker or Teamster), but there was no clear consensus among protest groups about whether the WTO itself should be abolished or reformed. But it was clear that virtually all protesters in the streets of Seattle sought to democratize and incorporate values other than profit-making into

of the rules take 1994 tariff and subsidy levels as the starting point, so the Southern countries that typically had less extensive sets of tariffs and minimal agricultural subsidies were prevented from adding new ones, even as they were forced to compete in a market dominated by countries that had relatively high tariffs and subsidies to protect their domestic industries (see Khor 1999). ${ }^{9}$ For instance, members of the International Forum on Globalization's board of directors, including Laurie Wallach and Martin Khor, among others, reported providing analyses of trade issues for government officials. 
global economic institutions.

These goals could not be promoted effectively in national contexts for a number of reasons. First, for citizens of countries with small markets and little economic power, attempting to affect their own countries' policies was useless, since these governments could have little impact on the ultimate outcomes of international processes. Second, in countries like the United States (as well as within global economic institutions), economic policies are considered technical, not political, decisions and are conducted largely in the U.S. Treasury Department and in the Trade Representative's office by trade bureaucrats. These offices are not open to democratic scrutiny, and often the protection of corporate and trade secrets justifies this lack of transparency. Most citizens know very little about these offices and are quickly deterred by the technical language used by Trade and Treasury officials. Third, the WTO agreement has removed key decisions from national policy debates, making the multilateral WTO agreement itself a target, since it limits the ability of citizens from all member governments to affect even their own local and national policies. Thus, in order to affect the issues protesters sought to address, national political action was insufficient. Even in the United States, which wields the strongest influence in the WTO, citizens cannot simply work within domestic contexts to affect changes. They may seek to influence U.S. policy within the WTO, but they gained leverage and greater potential for impact by also engaging multilateral political negotiations and by exploiting differences among states.

\section{Movement Origins: Mobilizing Structures and Collective Identities}

The varied constituencies making up the resistance in Seattle grew out of a history of local, national and transnational popular mobilizations around the world that have opposed regional and bilateral trade liberalization agreements, the policies of the World Bank and International Monetary Fund, and failures of nation-states to protect human rights and the environment. What is novel about recent protests is that they involved substantial numbers of U.S. citizens and citizens from other advanced industrialized countries mobilized in contentious 
opposition to the policies of an international organization. This mobilization also involved an extensive web of transnational associations and movement networks that facilitated cooperation and political exchange across national boundaries, and it also built upon streams of activism that developed over the 1980s and 1990s.

The organizations most prominent in the Seattle protests were also involved in prior mobilizations around global trade and multilateral financial policies. Labor organizations, consumer groups (most notably Nader's Public Citizen) and major environmental organizations in North America began paying greater attention to trade liberalization policies during the negotiations around the Canada-U.S. Free Trade Agreement (FTA) and subsequent North American Free Trade Agreement (NAFTA) (See, e.g., Audley 1997; Aaronson forthcoming; Ayres 1998; Shoch 2000; Naím 2000). But the opposition to neoliberal trade policy in Seattle can be traced to even earlier roots. Perhaps the first stream of resistance began in developing countries themselves, where resistance to IMF-imposed structural adjustment policies arose as countries of the global South sought to address a mounting problem of international debt (Walton and Seddon 1994). Environmental and human rights campaigners increasingly found themselves involved in efforts to curb World Bank lending for projects that threatened peoples and ecosystems in the global South (Fox and Brown 1998; Keck and Sikkink 1998; Rich 1994). Resistance to global economic policies in the global South drew the attention of Northern peace activists in the 1980s, and many of the older activists in Seattle, particularly those mobilized around "Jubilee 2000" or affiliated with peace movement organizations like the Women's International League for Peace and Freedom, could trace their opposition to global economic policies back to the 1980s mobilizations around third world debt and its relationship to conflict and economic justice in Central America and other developing regions (see, e.g., Smith 1994; Marullo, Pagnucco and Smith 1996). Partly as a result of these various struggles, the annual World Bank/IMF meetings eventually became sites of protest rallies of various sizes beginning in the late 1980s (Scholte 2000; Gerhards and Rucht 1992), and an international "fifty years is enough" campaign emerged in the mid-1990s to mobilize against the 1995 "celebration" of the 
fiftieth anniversary of the Bretton Woods conference and the founding of the World Bank and IMF (Foster 1999:145-153; Cleary 1996: 88-89).

Research on social movements has shown that formal social movement organizations (SMOs) play important roles in framing movement agendas, cultivating collective identities, and mobilizing collective actions. At the same time, churches, community organizations, friendship networks, and professional associations often engage in similar kinds of protest-oriented activities (even though these are not the principal purposes of these organizations) while providing resources for movements. The more routine contacts of these "extra-movement" groups with broad segments of society promote wider participation and legitimacy for social movements (McCarthy 1996;C. Smith 1996). The anti-WTO protests were comprised of a large number of “extra-movement" organizations and informal networks such as churches and professional associations whose principal organizational purpose is something other than furthering social change goals. This, however, does not preclude them from being important, if not central, participants in social movements. For instance, many churches and unions have standing committees that work on social justice or solidarity issues, thereby bringing at least some segment of these organizations into regular contact with social movements. Many labor unions from around the United States provided logistical and financial support that enabled their members to participate in an entire week of protest and educational activity. ${ }^{10}$ Also, as in other movements, churches played an important role by disseminating information about the protests and by providing meeting spaces, legitimacy, and other resources. Jubilee 2000 was based largely in

${ }^{10}$ Labor organizations have typically been considered outside at least the contemporary U.S. social movement sector because of their historical association with institutionalized politics and their tendency to focus on member services and contract negotiations rather than class struggle. In practice, some U.S. labor organizations resemble SMOs in their approach to struggle, most notably the longshore worker's union, which has traditionally emphasized radical confrontation and class solidarity (Levi and Olson 2000). The experience of labor in the Battle of Seattle and contemporary debates within the AFL-CIO suggest a possibility that labor issues could take a more contentious turn vis-a-vis political institutions. Social movement scholars may find need to re-think their assumptions about relationships between the social movement sector and organized labor in the U.S. 
churches and faith-based social justice organizations, and a substantial number of protesters were drawn to Seattle through their association with that campaign. School groups, in particular those organized to oppose sweatshop labor, also helped raise awareness of and generate participation in protests. In addition, organizers of the protest events in Seattle worked consciously to cultivate ties with community groups and with an active social movement sector in the Pacific Northwest. ${ }^{11}$

But the Seattle protests also built upon transnational mobilizing structures that shaped the organizational leadership, strategies, and tactics that organizers adopted. For instance, the rapid expansion in the numbers of transnational social movement organizations (TSMOs) during the past fifty years provided a growing number of activists with substantive knowledge of the political views of groups from different parts of the world, opportunities to gain skills and experience in international organizing work, expertise in international law, and familiarity with multilateral negotiation processes (Sikkink and Smith, forthcoming). The growth of TSMOs generated opportunities for transnational dialogues on conflictual issues and helped organizers combine interests and coordinate policy proposals that account for the needs and interests of people in both the global North and South. By facilitating flows of information across national boundaries, organizations with transnational ties cultivate movement identities that transcend nationally-defined interests and identities. In other words, they have helped cultivate organizational, movement, and solidary identities with a global emphasis (cf. Gamson 1991). ${ }^{12}$ Such negotiation of identities is crucial for sustaining any long-term social movement mobilization, and groups seeking to build alliances across national boundaries (e.g., where routine

${ }^{11}$ The Internet site for one of the main umbrella coalitions, People for Fair Trade (supported and initially staffed by Ralph Nader 's Public Citizen/ Global Trade Watch) provided tools for community organizers and organized neighborhood working groups on the WTO in preparation for the Ministerial meeting (www.peopleforfairtrade.org/).

${ }^{12}$ According to Gamson (1991), organizational identities result from activists' association of their personal identity with a particular SMO. Such identification can precede or lead to movement and solidary identities. Movement identities refer to the association of the goals and values of a movement with one's own, and solidary identities involve the inclusion of the individual or group in a wider community of fate. Examples of the latter would include class identities or identities such as victims of corporate exploitation. 
face-to-face contact is rare) in particular must engage in deliberate efforts to define "who we are" if they are to sustain activists' commitment.

Transnational SMOs must demonstrate wide geographic representation if they are to be effective in multilateral political arenas. The ability to show that one's organization engages participants from many different countries helps lend credibility to the organization's agenda within multilateral settings, and it is therefore a central criterion used by the United Nations to determine whether the group merits official accreditation. It also provides an organization with access to first-hand information on conditions in a variety of countries, facilitating efforts to link local examples to global policy debates. But cultivating such a diverse membership requires that these organizations create spaces for transnational dialogues and negotiations about common goals and strategies (Smith, Pagnucco and Chatfield 1997). While most protesters were from the United States and Canada, there was substantial representation from other parts of the world, particularly among the speakers at protest rallies and teach-ins. ${ }^{13}$ Many of the activists from poor countries who traveled to Seattle did so as a consequence of their participation in transnational associations. ${ }^{14}$

In the process of building coalitions and negotiating joint strategies, activists learn each others' positions and, where conditions favor it, build relationships and trust that are crucial for ongoing cooperation (Rose 2000). For instance, while Western environmental and labor activists might accept a policy of promoting environmental and labor protections through existing WTO mechanisms, dialogues with their counterparts in developing countries led to a position opposing the extension of WTO authority into other areas. As a result, the common statement endorsed by nearly 1500 citizens ' organizations from 89 countries called on governments to adopt "a

\footnotetext{
${ }^{13}$ Activists and scholars from the global South were $30-40 \%$ of the panelists at the largest protest rallies and People's Assembly

${ }^{14}$ Data on transnational social movement organizations shows a trend towards greater participation from countries in the global South (Smith 2000). Moreover, the Ministerial's location affected the under-representation of Southern activists. United Nations conferences held in the global South drew substantially larger numbers of representatives from Southern organizations (Clark et al. 1998; Smith, Pagnucco and Lopez 1998).
} 
moratorium on any new issues or further negotiations that expand the scope and power of the WTO" and to review existing agreements and address their negative impacts on human and labor rights, health, women 's rights, and the environment. ${ }^{15}$ While it is difficult to determine the impacts of these kinds of joint statements, the process of preparing the statements and, for many groups, the decisions about whether or not to sign on to them, can involve extensive group deliberations about shared interests and identities.

Table 1 maps the structure of major organizational participants in the anti-WTO actions in Seattle. What we hope to learn here is whether the participants in this event were principally national or transnational organizations and whether transnational groups differed from more localized ones in the types of roles they played in the mobilization. Prevalent roles for transnational organizations would suggest that globalization processes, like the consolidation of the modern nation-state in the $18^{\text {th }}$ century (Tilly 1984), are affecting the ways that people associate for political purposes.

\section{Table 1 About Here}

While the table is not an exhaustive list of organizations participating in protest events during the WTO Ministerial meeting of 1999, it does include the organizations most directly involved in organizing protest activities and forums and in mobilizing activists to participate in protest events. The table helps reveal an important division of labor between groups with formalized transnational ties and those with diffuse ties. The groups with no ties or with more diffuse transnational ties and also more informal and decentralized organizational forms were principally involved in mobilizing and education as well as in the coordination of efforts to "shut down" the meetings.

${ }^{15}$ The "Statement from Members of International Civil Society Opposing a Millennium Round or a New Round of Comprehensive Trade Negotiations" can be found at: www.citizen.org/pctrade/mai/Sign-ons/WTOStatement.htm. 
Groups with more routine and formalized transnational connections were also involved in education and mobilization, but they tended to play more important roles in framing and informing the broad protester critiques of the global trading system, lobbying government delegations, and relaying information from official meetings to protest groups that lacked official accreditation. They supported other groups' mass mobilization efforts by, for instance, developing educational materials, speaking at rallies and teach-ins, and bringing in speakers from the global South. In many ways, these groups were the international specialists that had ready access to detailed information about WTO processes and regulations, could produce examples of the effects of global economic policies in multiple countries, and that frequently had privileged access to official documentation and government delegations. As in national contexts where the different foci of locally based groups and those in national capitols create rifts in group identities and perceptions, there was some evidence of conflict across this division of labor, but this did not appear to seriously detract from protest efforts in Seattle.

Groups with no formal transnational ties are principally local chapters of national groups and local groups formed around the anti-WTO mobilization. In addition, United for a Fair Economy is a national group focused on critiques of inequalities in the U.S. economy. These groups were important to the mobilization of local activists to participate in Seattle protests, and often they worked with or were mobilized because of groups like Direct Action Network, Public Citizen, or others with more extensive transnational ties. Groups with diffuse ties include regional organizations whose memberships cross the U.S.-Canada border and or groups with other transnational ties that grow out of their organizing efforts. For instance, the Berkeley based Ruckus Society (whose leaders include former Students for a Democratic Society organizers) primarily brings together Canadians and Americans for nonviolence training. The Coalition for Campus Organizing works to facilitate progressive organizing on college campuses, and it has taken on international work focusing on sweatshops and educational issues, including those raised by the WTO General Agreement on Trade in Services (GATS). ${ }^{16}$ Its international work

${ }^{16}$ The GATS agreement progressively opens trade in services just as traditional trade agreements 
has led to cooperation with student organizations in Canada.

Organizations listed as having "routine" transnational ties typically are national organizations whose main organizational work is at the national level but which have staff devoted to international organizing or solidarity-building, have formed standing committees for work on international issues (e.g., Sierra Club, AFL-CIO, Public Citizen) or whose operations involve routine communication and sustained cooperation with activists from other countries (e.g., Global Exchange, USAS). In practice, the transnational interpersonal and inter-organizational contacts these organizations develop can substantially affect their organizational agendas and frames.

In contrast to these associations, organizations with formal transnational structures incorporate transnational cooperation and communication into their operational structures. Groups like Greenpeace and Friends of the Earth have a federated structure, with national level branches that help disseminate information on global campaigns and tailor it to national needs. The headquarters of these organizations facilitate research and information exchange and, in the some cases (i.e., Friends of the Earth and Greenpeace), conduct global level direct action protests as well as lobbying. The International Forum on Globalization (IFG) represents another transnational organizational form that is appropriately labeled as a "cadre organization." A collection of experts on globalization issues from around the world, the IFG has, since its founding in 1994, produced educational materials and organized "teach-ins" on the impacts of global financial integration. IFG leaders have been called "paradigm warriors" to reflect their role in advancing public debate about corporate globalization and its consequences. Third World Network has a similar structure, though it consists entirely of scholars and experts from the global South. Peoples Global Action (PGA) is a loose coalition of organizations from around the world with a web site, but no formal organizational headquarters. PGA involves a large number of groups from India and other parts of the Global South that first came together after Zapatista

served to open markets for trade in goods. Such services range from banking and finance to public education, utilities, and health, which were on the agenda for the failed Seattle talks. 
organizers issued an electronic call for an international meeting of like-minded groups (PGA 2000). It has convened several international meetings on globalization since the mid-1990s and supported public protests at earlier meetings of the WTO and G-7 countries. The 50 Years is Enough Network is one example of what may be an increasingly common coalition organizational form. ${ }^{17}$ Rather than having national branches, this type of organization allows organizations who share the Network 's views to join as coalition partners and to participate in joint statements and actions. This maintains the autonomy of local and national groups while allowing them to stay informed about global issues and to choose how active they wish to become in global campaigns. While more can be said about these organizations, the important point here is that they all incorporate formal mechanisms for sustained, routine transnational communication and cooperation..$^{18}$

The organizational makeup of extra-movement mobilizing structures that contributed substantially to the Seattle protests also demonstrate important transnational linkages. The International Confederation of Free Trade Unions (ICFTU), for instance, held its annual conference in Seattle just prior to the WTO gathering, bringing with them labor leaders from over 100 countries. International exchanges promoting labor solidarity forced U.S. labor leaders in particular to confront the more isolationist and nationalist positions that have characterized large U.S. unions in the past. Given that the religious and class identities they promote transcend national boundaries, churches and labor unions often promote transnational exchanges among their members (C. Smith 1996). Such exchange might include missionary work, solidarity work to support organizing efforts of affiliated unions or churches, and fact-finding visits aimed at cultivating shared identities and mutual support. Because they help link global identities and

\footnotetext{
${ }^{17}$ Smith (1997) found that transnational SMOs formed after 1970 were more likely than those formed in earlier decades to take the form of coalitions (organizations of organizations) rather than federations (a hierarchical structure of transnational organization with affiliated national sections).

${ }^{18}$ With the exceptions of Greenpeace and Friends of the Earth (both formed in 1971) and Third World Network (formed in 1984), the transnational SMOs listed here were formed during the 1990s.
} 
interests with people's routine social activities, to the extent that labor and religious alliances can be sustained in this movement to transform the global trade regime, they will be important structures for advancing transnational mobilization and dialogue to a more general audience.

This overview of the organizational makeup of the Seattle protests demonstrates that globalization processes have affected the ways that social movements mobilize and organize. It reveals substantial transnational ties among some of the key organizations behind the protests and suggests a division of labor between transnational and national or locally-oriented organizations. Transnational ties range from diffuse ones which grow out of shared purposes to more formal links institutionalized in transnational organizational structures. In between, we find a number of national movement organizations innovating organizational mechanisms to help them incorporate new levels of transnational communication and cooperation into their ongoing movement work. Groups with more routinized transnational structures appeared to be more involved in lobbying and gathering information on WTO negotiations while more national and local groups helped disseminate information and mobilize protesters. While this paper presents only a snapshot of the actors in a single transnational protest event, seen in conjunction with prior mobilizations and with other evidence on transnational SMOs (Smith 2000), the data support the argument that social movements have developed more formalized, integrated, and sustained organizational mechanisms for transnational cooperation around global social change goals. This organizational development is reinforced by the political demands of the global policy process as well as by the political socialization and globally-oriented identity construction that takes place within this movement. Such socialization helps participants not only develop critical understandings of global interdependencies and policy processes, but it also builds relationships and trust across boundaries by cultivating shared organizational, movement, and solidary identities.

\section{Global Political Processes and Movement Tactics}

Changes within the global political order, or global polity, parallel the change processes that characterized the much earlier rise of national polities (cf. Tilly 1984). Specifically, they 
both involved cooperative and conflictual interactions between states, polity members, and challengers. Global institutions are formally controlled by states, but historical analyses have shown that social movement challengers have played influential roles in defining the structures and purposes of these institutions through their interventions in domestic and multilateral policy processes (Chatfield 1997; Finnemore 1996; Meyer, Boli, Thomas, and Ramirez 1997; Smith 1995). States are nested within an increasingly complex and consequential web of transnational relations and institutions which both increase their ability to limit external threats -- such as those arising from financial and environmental interdependence -- while at the same time expanding their vulnerability to social movement challengers. Vulnerabilities arise as multilateralism creates new arenas for challengers to question state agendas, draw international attention to domestic practices, and to cultivate alliances with powerful actors outside the domestic political arena, including other states. At the same time, the centralization of political authority at the global level raises the costs of effective political challenges. Contenders seeking to defend or shape local policies governed by expanding global political arenas must mobilize resources for a much broader arena of political action if they hope to affect local changes that are governed by international institutional arrangements.

If political authority is in fact moving towards global institutions, then we should expect to find the kinds of changes in social movement repertoires that Tilly observed with the rise of national polities during the $19^{\text {th }}$ century. Novel to that period were the formation of special-purpose associations and the targeting of more remote, national structures by collective actors. These changes paralleled the rise of national electoral politics:

The distinctive contribution of the national state was to shift the political advantage to contenders who could mount a challenge on a very large scale, and could do so in a way that demonstrated, or even used, their ability to intervene seriously in regular national politics. In particular, as electoral politics became a more important way of doing national business, the advantage ran increasingly to groups and organizers who threatened to disrupt or control the routine games of candidates and parties. (Tilly 1984:311) 
By the late twentieth century, the growth of international institutions appears to have shifted at least some political advantage to contenders operating on a transnational scale who can intervene regularly in inter-governmental political processes. Social movements and corporate actors wishing to protect certain interests or to resist infringements on existing rights have found that they can only do this by building capacities for monitoring and participating in transnational political processes. ${ }^{19}$

Does Seattle provide evidence to support this interpretation? Table two lists some of the major protest activities employed during the anti-WTO protests, categorizing them according to their relationship to well-established protest forms. We would expect protest repertoires to overlap substantially during periods of fundamental restructuring of economic and political relations, just as "old," pre-national protest forms co-existed during the rise of national protest repertoires. Moreover, because global institutions are based on constitutional forms consistent with Western state institutions, I do not expect there to be much evidence for the abandonment of protest forms developed within that institutional context. However, we should expect that national protest forms are being adapted to target not just the domestic policies of states but also their international policies as well as the policies of international institutions.

Table 2 About Here

\section{Adapting the Repertoire}

The left hand column of table 2 lists examples of adaptations of older protest forms to global political arenas. Many of these tactical adaptations involve simply the transfer of movement target from the nation-state to the international policy arena. Thus, the age-old

${ }^{19}$ The advantage of transnational mobilization certainly varies according to issue. Whereas human rights and some environmental activists find natural and necessary connections to multilateral processes, other areas, such as the abortion debate, are less directly affected by multilateral policies and require more local and national emphases. 
blockade continued to serve movement purposes by physically preventing international meetings from taking place. And street protests and rallies served --as they have with national protests -- to dramatize the worthiness, unity, numbers and commitment (see McAdam, Tarrow and Tilly, forthcoming) of groups that support a social movement 's goals. These protest forms were amplified by an "International Day of Action," called on November 30 to coincide with the opening of the WTO conference. "N30" protests targeted financial centers in numerous cities as well as United States embassies on the pre-determined day of mass protest at the Seattle meeting. One account reported demonstrations in multiple cities of more than 20 (mostly Western) different countries, including Australia, Canada, Colombia, Czech Republic, Germany, Greece, India, Pakistan, The Philippines, Spain, and Turkey, (www.n30.org). Protests in London, France, Mexico, and India were among those resulting in property damage and/or other violence.

Education and Mobilization. An important part of the protests in Seattle and elsewhere were educational actions, which included speaker panels and other events to educate the public about economic globalization and its effects on local policies and democratic institutions. "Teach-ins," first used in the anti-Vietnam war protests (Gamson 1991), were employed throughout the United States and Canada (and possibly elsewhere) to educate citizens about the global policy process and the rules and consequences of the WTO. They served as important low-cost and low-risk opportunities for sympathizers to begin or reinforce their involvement in the movement. In Seattle, many of these teach-ins brought together labor activists with other groups, enabling dialogues that were unlikely to happen elsewhere. As was true of the first teach-in, these events were spaces where participants' commitment and identity with a growing movement and with other victims of "corporate-led globalization" was cultivated. Rather than focusing on the national policies of the U.S., the emphasis of speakers at these events was on the entire global trade regime and the variety of state policies that shape and are shaped by this regime. While mass media coverage of the anti-WTO resistance focused on the street protests, more long-term damage to official trade policies may have been done in the churches, union halls, and schools where activists and the public were engaging in global civic education. 
Activists furthered their mobilization efforts by encouraging organizing around the Seattle event among groups such as students, churches, and other social movement groups, and by drawing new sympathizers into existing organizations and networks. A particular effort was made -- primarily by the Direct Action Network -- to develop "affinity groups" that would allow coordination among activists while preserving local participation, flexibility and responsiveness, and helping provide protection from police repression. Such affinity groups resembled strategies used in earlier U.S. movements and is characteristic of the large anarchist contingent in the Seattle protests. Also assisting efforts to resist police repression were efforts by groups like the Ruckus Society and DAN to educate activists about nonviolent action and prepare them for confrontations with police. Training workshops in nonviolence, first aid, and legal observation supplemented others promoting skills like puppet-making and banner hanging.

Public protests also served to generate awareness of issues and to encourage sympathizers to become involved in the movement. Although protests typically rely upon media coverage to help spread their message, they also serve movement-building functions by motivating and encouraging movement sympathizers and adherents (see, e.g., Lipsky 1968). Mass rallies and protests create a relatively (in many Western contexts) low-cost means for people with limited knowledge of an issue to learn about and begin their involvement in a movement. Moreover, the act of protesting creates and nurtures activist identities by dramatizing conflict and polarizing identities in "us versus them" terms. It can generate new levels of commitment on the part of both new and long-term activists (see McAdam 1988; Gamson 1991). When protesters face repression by agents of the state-particularly the extreme physical violence and large numbers of arrests used in Seattle - this effect is amplified.

Protest also affects the dissemination of information about movement goals to a wider public. The participants in protests affect the ways their own organizations and informal networks of family and friends perceive the protests and interpret media frames. They do so by providing alternative sources of information from mainstream media frames or by encouraging friends and kin to pay greater attention to the public discourse on the protests than they otherwise 
would. In addition, when protesters themselves interact with bystanders near protest settings, they can convey different, humanized interpretations of the protest purposes and goals than the mass media might.

Another strategy for mobilizing new sympathizers into the movement involved the adaptation of a previous protest form to promote "MAI free zones." This tactic grew from the successful campaign during 1998 to block a Multilateral Agreement on Investment, a "bill of rights for investors" which would have liberalized rules on international investment (see Barlow and Clarke 1998). Activists argued that governments were seeking to revive the MAI in various elements of the WTO negotiations, threatening to restrict the ability of local governments to control local economic decisions. The MAI was thus seen as a fundamental threat to democratic decision making at the local level, presenting the possibility of recruiting local public officials to the anti-WTO cause. Drawing from the 1980s tactic of declaring "nuclear free zones," movement organizers helped raise questions about how this particular global policy would affect local interests, thus helping to educate local legislators and the public about the ways the WTO agreement impinged on local authority and democracy. It also helped the movement win over some influential and credible allies to their cause. The fact that the Seattle city council declared the Ministerial site an "MAI-free zone" set an ominous tone for visiting trade delegates who faced an agenda full of proposals to advance variations of the MAI within the WTO framework.

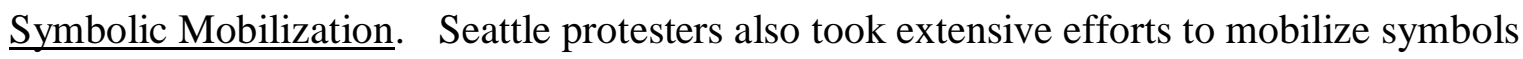
and to otherwise frame their messages. Public Citizen and other well-resourced organizations sponsored an NGO press center and organized press conferences for mainstream and alternative media representatives. More provocative groups wrapped copies of Seattle Post Intelligencer with a satirical headline page titled The Voice of the People. Headlines like "Jordan Gives Nike the Boot/ Joins Worldwide Boycott," "Mumia Freed," and "Monsanto Patents Food Chain" (by Dolly Bah) greeted those purchasing papers from newspaper boxes near delegates' hotels and other conference sites.

Speakers at teach-ins and other educational events engaged in what might be called 
"global witnessing" of the effects of global economic policies in various countries. A tactic that emphasized such witnessing were transcontinental "caravans" across the United States and Canada that brought representatives of citizens' organizations from around the world to protest at the outlets and headquarters of U.S. corporations and to speak in local communities around North America about the ways globalization has affected their countries. ${ }^{20}$ These events gave human faces to global interdependencies and implicated Western industry and consumption practices in human suffering around the world. Some caravan speakers brought word of victories of local resistance against corporate globalization. The accounts from poor people around the world provided tangible testimony to counter officials' claims that the WTO's principal aim is to help poor countries. ${ }^{21}$ Reversing predominant flows of knowledge and assistance, a number of speakers from the global South expressed willingness to share their knowledge and experience in order to help their American counterparts understand corporate globalization and how to resist it. One panel included both third world activists and legislators from the U.S. and Canada, who remarked that the accounts they heard from Southern activists would help them face their neoliberal opposition in future legislative battles. ${ }^{22}$

Guerilla theater also played an important role in the Seattle protests. Greenpeace activists

20 The caravans were organized by groups associated with Peoples' Global Action, and the U.S. caravan suffered minor setbacks when U.S. officials denied visas to several participants.

${ }^{21}$ For instance, despite the ambiguous evidence of trade's affects on poor countries (see UNDP 1998, 1999), in the wake of the failed Seattle talks, WTO Director General Mike Moore stated: "I feel particular disappointment because the postponement of our deliberations means the benefits that would have accrued to developing and least-developed countries will now be delayed .... The longer we delay launching the [WTO expansion] negotiations, the more the poorest amongst us lose" (http://www.wto.org/wto/new/ press160.htm). For further detail on the discrepancies between economic data and the claims of trade advocates, see Mark Weisbrot, "Globalization for Dummies" Harper 300 (May 2000): 15-19; and Jackie Smith and Timothy Patrick Moran, "WTO 101: Myths About the World Trading System" Dissent (April 2000): 66-70.

${ }^{22}$ The panel on November 29, 1999, "Environment and Health Day" featured a "People's Tribunal" on "The Human Face of Trade: Health and The Environment." The "Tribunal" included U.S. representatives George Miller and Maxine Waters and MP Bill Blaikie from Canada, in addition to Magda Aelvoet, the Belgian Minister of Consumer Protection. Activists from Mexico, Malaysia, the Philippines, Trinidad, Pakistan, and Ghana addressed the "Tribunal." 
showered government delegates with bunches of condoms bearing the slogan "practice safe trade" from a balcony of one of the official meeting venues. A group of activists from the United States and Canada calling themselves "Art and Revolution" were a main source of "puppet-ganda" and street theater on WTO issues. The Direct Action Network promoted and facilitated puppet-making, contributing to the protests' festive atmosphere while providing opportunities for activists to engage a variety of different skills to convey political messages in creative, irreverent, and often humorous ways. Banner hangs, where activists risk arrest by scaling buildings and scaffolding to display massive banners, aimed at educating a wider audience about the issues at stake in global conferences. One Seattle banner that survived a few hours before police removed it displayed the word "WTO" with an arrow pointing in one direction followed by "DEMOCRACY" with an arrow pointing in the opposite direction.

Seattle protesters also employed adaptations of symbolic resistance such as the "Boston WTeaO Party." Here activists appropriated historical symbols of resistance to colonial rule, calling for "no globalization without representation" and dumping into Seattle's harbor rejected products such as shrimp caught with nets that kill endangered sea turtles and steel imported at prices below U.S. production costs. While the WTeaO Party took place, a hero of global protesters, José Bové, resisted globalization not by smashing McDonald 's restaurants but by distributing nearly 500 pounds of embargoed Roquefort cheese amid a chorus of protesters ' cheers. $^{23}$

Disruption. Disruption and confrontation was an important emphasis of many protesters in Seattle, and certainly these activities left the most lasting impressions on much of the mass media audiences watching Seattle's events. The main protest web site and mobilizing flyers called upon activists to "Shut Down Seattle" during the WTO meeting. The direct action training focused on blocking access to the meeting site in order to prevent an agreement to expand the

${ }^{23}$ The United States had outlawed the importation of Roquefort cheese and other luxury products after the WTO backed its claim that the EU ban on the import of hormone-treated beef violated trade laws. 
agenda of the WTO. Using "lock down" and "tripod" ${ }^{24}$ strategies where activists risked serious physical harm in order to complicate police efforts to remove them, protesters occupied key intersections and forced delegates to stay in their hotels for much of the first meeting day. Delegates who were out on the streets after being turned away from the meetings were "lobbied" by activists taking the opportunity to present their critiques of the WTO and proposals for its expansion. The use of the decentralized, affinity group strategy complicated police efforts to respond to protest actions, contributing to both their diversity and effectiveness (Gillham and Marx 2000).

The activists' blockade rather than property damage actually triggered the initial police response of indiscriminate use of tear gas by mid-morning on November 30 (Author's observation notes; Ackerman 2000:63). Apparently frustrated by their inability to guarantee delegates' access to the opening ceremony, police took this desperate measure in an effort to clear a path for delegates and prevent the cancellation of the opening session. Anarchist groups, who had announced over protest electronic list servers their intentions to target downtown shops, did not use violence until after the authorities began the cycle of violent confrontation, which escalated into what was essentially a police riot.

Other forms of nonviolent civil disobedience abounded throughout the week. Some of this activity was directed at communicating protester messages to delegates. Some of the first arrests were of organizers from Global Exchange who - wearing their NGO access badges that allowed them into the opening ceremony - took the podium and the opportunity to address the handful of delegates who managed to pass through the barricade about the concerns that brought them to Seattle that day. Outside the hall, delegates from the People's Tribunal against Corporate Crimes were arrested as they crossed police lines to deliver their "indictment" to the

24"Lock-downs" involve the use of chains, bicycle locks, clamps, and PVC pipes to link activists' limbs, making the involuntary removal of any one of the lock-down participants hazardous. The tripod involves three tall poles that are arranged in a tripod and secured by three activists. One activist climbs the poles and sits on or hangs from the tripod. To remove the barricade without causing injury, authorities must bring in a crane or fire truck. 
leaders of Western industrialized countries of the G-8. Many more protesters were moved by police crackdowns to engage in disruptive protest against the system that they saw brutalizing nonviolent citizens and denying First Amendment rights. Clogging up jails and hampering police booking procedures through "jail solidarity"(refusing to give names until all arrestees were guaranteed reduced sentences), protesters adopted some classic forms of civil disobedience developed through civil rights and anti-Vietnam war era protests.

\section{Innovative Repertoires}

While many of the Seattle protesters ' tactics reflect adaptations of earlier repertoires, we see some evidence of tactics that are innovative, not in the sense of novelty, but rather in that they have been developed to target multilateral political processes. Transnational associations are not new, but they are relative newcomers to the protest repertoire, and the last half-century especially has seen an explosion in their numbers. And experiences of activists over the course of $20^{\text {th }}$ century efforts to shape the League of Nations and later the United Nations have led to "innovations" in the national protest repertoire. Moreover, these tactics often rely on new technologies-- ironically the same ones that have fueled the global economic expansion the protesters resist.

Organization/Mobilization. One of the most basic innovations is the creation of transnational associations. Other mobilizing innovations include the production and distribution of a nongovernmental organizational newspaper that presents counter-hegemonic interpretations of official intergovernmental negotiations and highlights the proposals and activities raised by challenger groups during the several days of inter-governmental conferences. Such newspapers have become a routine fixture at intergovernmental conferences on contentious issues, and they have proved important in pressing governments to take up concerns of challenger groups and in providing alternatives to great-power dominated conference frames. They have been used at many inter-governmental conferences, including those on nuclear disarmament, Law of the Sea, human rights, and women 's and environmental issues (Atwood 1997; Clark, Friedman, and 
Hochstetler 1998; Levering 1997; Willetts 1996). ${ }^{25}$

Borrowing Official Templates. Activists in Seattle and other multilateral contexts engaged in efforts to structure their collective action around official templates. Thus, one of the main coalitions of organizations in Seattle organized a "Peoples' Assembly" to parallel official deliberations. In order to incorporate the variety of issues and groups motivating activists, each day was devoted to panels centered on a different agenda item such as environment and health, women, human rights, labor, and agriculture.

Another way that challengers borrow official forms is by getting sympathetic experts or even movement activists onto national delegations to international meetings. Because international negotiations often involve very technical aspects of science and policy, governments must look beyond their traditional diplomatic corps to fill their delegations. In some fields, such as human rights, environment, and women's issues, some of the most widely respected experts are social movement activists. Their expertise on the issues at stake as well as their familiarity with the international negotiation process makes transnational activists a rich resource for governments seeking to influence negotiations. While they are obviously not likely to appear on delegations of countries opposing the changes they seek, activist experts may be invited to sit on delegations of countries that are sympathetic with their change goals. Or they may force their way onto a delegation by using national laws such as the U.S. Federal Advisory Council Act that requires government advisory panels at international meetings to represent a fair balance of viewpoints. ${ }^{26}$ When movement activists or sympathizers find their way onto delegations, they often serve as important conduits of information between official and popular forums.

${ }^{25}$ Many of these cases show that government delegates from some (especially poor or less central) states have come to rely on movement publications, particularly the newspaper, for information on technical aspects of the problems under negotiation and/or the political processes surrounding the negotiations.

${ }^{26}$ Environmentalists had to sue the U.S. Trade Representative ' s office in order to have this law respected and their viewpoints reflected in the makeup of trade advisory panels on paper and wood (World Trade Observer November 18, 1999, p. 1; also available at www.worldtradeobserver.org). As a result of the decision, Friends of the Earth-U.S. president Brent Blackwelder joined the U.S. delegation as a Trade Advisory Council member. 
Another form of official template-borrowing involves dramaturgy in the application of international legal principles and routines. In Seattle, a "Global People 's Tribunal on Corporate Crimes Against Humanity" was organized by the Program on Corporations, Law and Democracy and the National Lawyers Guild Committee. Its purpose was to assemble and present research on corporate practices around the world. "Witnesses" included a former sweatshop worker from the Philippines who had worked for a Gap subcontractor until she was fired for promoting union activities, a farmers' organization representative from India discussing the effects of Monsanto ' $s$ seed marketing practices on Indian farmers, and an Indian medical doctor who treated victims of Union Carbide' s 1984 chemical disaster in Bhopal. The lawyer-activists facilitating the event educated the audience and "jury" on the relevant international law and tribunal procedures, and the Tribunal issued an "indictment" for crimes against humanity of the governments under whose laws the guilty corporations were established. ${ }^{27}$ The appeal to international law against state and corporate practices serves to emphasize the legitimacy or worthiness of the protesters' cause even in the authorities' own terms.

Electronic Activism. Perhaps the most significant innovations in protest forms result from the same technological innovations that have advanced economic globalization, namely, electronic communications and exchange. These were likely introduced simultaneously to both national and transnational protest repertoires as technologies facilitating inexpensive transnational communications became widely available. Both national and transnational social movement groups have made extensive use of Internet sites and electronic list serves to expand communication with dispersed constituencies and audiences. These communication networks allowed organizers to almost instantaneously transmit alternative media accounts and images of protests to contrast those of mainstream, corporate-owned media outlets. These alternative electronic media networks also helped to rapidly disseminate information about resistance against

27 People's Tribunals were also used during protests against the Vietnam war, and during United Nations conferences. Their appeals to international human rights law and direct allusions to international legal proceedings following WWII make them tactical innovations. 
economic globalization in the global South, such as the Mexican student strikers, whose conflict escalated shortly after the Seattle protests as strikers rallied in solidarity with the jailed Seattle protesters. They also undermined authorities' legitimacy by facilitating the transmission of police radio communications during the crackdown on protests.

Rather than rely solely on the mainstream media to convey the images of the protests to the general public, activists organized an "Independent Media Center" (IMC) in Seattle, issuing press badges to volunteer photographers, video recorders, and reporters (no formal credentials necessary) wanting to cover the protests. IMC volunteers had access to a press office and could post their reports, pictures and video (some for direct cable broadcast) onto a web site linked to other movement sites.

Electronic civil disobedience also becomes possible as commerce and other essential activities are linked to the flow of electronic information. Anti-WTO protesters who could not get to Seattle could satisfy their desire to join in the protests by engaging in electronic "sit-ins" at the WTO Internet site to block other information-seekers ' access to the site. In addition, at least one hacker developed a "mirror" site that drew in unwitting information seekers who thought they were viewing the official WTO web page, providing them with a subtly different site that highlighted criticisms of the organization (Seattle Post Intelligencer, November 29, 1999, p. A1). More confrontational "e-protest" takes the form of e-mail and fax-jamming, where large faxes (e.g., protest letters written one word per page) and e-mail messages are sent to disrupt routine flows of information to targets.

Reviewing the tactics employed in Seattle, we find a protest repertoire that both adapts forms that have been typical of national social movement repertoires and expands the repertoire to address multilateral institutional arenas. This protest repertoire can be attributed to the global-level reorganization of political and economic relations in which challengers themselves play a role. I have argued that the events in Seattle should be examined as part of a more continuous process of evolving forms of contentious politics that began late in the $19^{\text {th }}$ century, but gathered momentum especially during the latter half of the $20^{\text {th }}$ century, through which 
challengers have increasingly sought to influence international policy and processes (see, e.g., Chatfield 1997; Keck and Sikkink 1998). The Battle of Seattle, then, was not the first, nor is it likely the last in the contest to shape the course of global economic, political, and societal integration. It is rather part of an interactive process of contention between elites and popular challengers that is likely to have implications for the course of future conflicts.

\section{Conclusions}

This examination of the Battle of Seattle revealed that protests around global trade liberalization involve extensive transnational mobilizing structures that are likely to (and, indeed, already appear to have) develop further as a consequence of the Seattle mobilization and its impact on collective identity formation. It also showed evidence that tactical repertoires have been altered in specific ways, indicating growing experience with attempts to target actors other than nation states. While states are often the ultimate target of policy changes, challengers face a more complex system of "multi-level governance" (Marks and McAdam 1996) or "complex multilateralism" (O'Brien et al. 2000) whereby the relations among states become important resources or obstacles to challengers' attempts to impact a given state. For instance, in the WTO arena, United States economic policy depends upon support from its European allies. The unity of Western positions was challenged by mobilizations against trade in genetically altered foods, making U.S. insistence on unlimited trade a threat to its alliance with other Western states. This case also dramatizes how intergovernmental institutions themselves provide targets for mobilization of people in different national settings around common policy goals.

When considering the impact of globalization on popular protest, however, the crucial question is not whether globalization diminishes the power of states or the importance of national political processes, but rather how international institutions affect abilities of both states and other elites as well as challengers to influence global political processes. Indeed, many international campaigns ultimately seek to change international policy by shaping the decisions of individual states, and therefore they urge participants to target their own (or sometimes other states') 
domestic policy processes. An important component of the success at Seattle were the rifts between the U.S. and European states over agricultural and safety issues and between rich and poor countries over the rules under which trade liberalization is to proceed. So while states indeed do control international institutions, they cannot control all aspects of the day-to-day operations of international organizations. Moreover, they do not stand together as a united front against all challengers. Some states may serve as movement allies on particular issues, or they may see their strategic interests served by movement opposition to other governments' policies. Global activists sought to exploit these divisions among states in their efforts to prevent any agreement at the Seattle Ministerial meeting.

There are other important questions about the impacts of globalization for protest. The repression faced by protesters should raise serious warning flags for scholars of social movements about the ways that globalization affects the practice of democracy (see, e.g., Markoff 1999). In one of the countries with the most staunchly defended right to free speech and assembly, government officials were able to successfully enforce an illegal "no-protest zone." Moreover, agents in support of the neoliberal trade regime revealed a blatant disdain for democracy. For instance, Slade Gorton, the Republican U.S. Senator from Washington State appeared on the local television news on the night of the N30 protests and vandalism, arguing that Mayor Schell should have declared the entire city a "no protest zone." This comment produced no immediate discussion despite its obvious disregard for the democratic process. Further contempt for democratic principles is apparent in a document from a pro-trade think tank, the Institute for International Economics, which suggests that a strategy for advancing U.S. trade interests should include efforts to eliminate public participation and democratic accountability by, for instance, obfuscating the terms used to refer to "fast track" executive authority. Such authority essentially eliminates a meaningful Congressional role in trade negotiations by forcing the legislative branch to either reject or approve the whole of agreements (Institute for International Economics 1999). ${ }^{28}$

${ }^{28}$ Clinton ' s earlier efforts to obtain "fast track" negotiating authority were defeated twice because of movement pressure. 
Former World Bank chief economist Joseph Stiglitz highlights this problem in his critique of the IMF: "Economic policy is today perhaps the most important part of America's interaction with the rest of the world. And yet the culture of international economic policy in the world's most powerful democracy is not democratic" (Stiglitz 2000).

Beyond infringements of democratic rights, states also retain the ability to inhibit mobilization by, for instance denying visas to activists (as the U.S. did for some Seattle protesters) and by scheduling global meetings in remote locations where democratic rights are not recognized. Singapore was the site of the 1996 WTO ministerial, and future meeting sites are likely to be considerably less open and accessible than Seattle. For instance, the Middle Eastern kingdom of Qatar is being considered as a possible site for the next WTO ministerial meeting. These and other possibilities for states to work together to raise the costs of protest through repression, counter-mobilization, and outright exclusion of activist groups must be considered as we continue to explore the impacts of globalization for democracy and contentious politics.

The Battle of Seattle has triggered a much broader public appreciation for the need to expand public discourse about global policies and to encourage greater transparency and accountability within these institutions. Activists outside the United States have been inspired by seeing protesters in what one of my informants called a "politically underdeveloped nation" stand up - even in the face of brutal repression -- to resist the neoliberal expansion that their own government has been championing for decades. The Battle of Seattle is one of the most significant recent episodes of collective action, and it points to a future of social movements that is increasingly global in both target and in form and that is in more direct confrontation with global institutions than its historical predecessors. 
Table 1: Mobilizing Structures Behind the

"Battle of Seattle" and N30*

\begin{tabular}{|c|c|c|}
\hline $\begin{array}{l}\text { Type of } \\
\text { Transnational } \\
\text { Tie }\end{array}$ & Movement $^{1}$ & Extra-Movement \\
\hline$\frac{\text { No formal TN }}{\underline{\text { ties }}}$ & $\begin{array}{l}\text { Local Chapters of National SMOs } \\
\quad(\text { e.g., NOW) } \\
\text { Neighborhood no-WTO Committees } \\
\text { United for a Fair Economy }\end{array}$ & $\begin{array}{l}\text { School groups } \\
\text { Friendship networks }\end{array}$ \\
\hline Diffuse TN ties & $\begin{array}{l}\text { Direct Action Network } \\
\text { Reclaim the Streets } \\
\text { Ruckus Society } \\
\text { Coalition for Campus Organizing }\end{array}$ & $\begin{array}{l}\text { Union Locals } \\
\text { Some churches }\end{array}$ \\
\hline$\underline{\text { Routine TN ties }}$ & $\begin{array}{l}\text { Public Citizen } \\
\text { Global Exchange } \\
\text { Rainforest Action Network } \\
\text { United Students Against Sweatshops } \\
\text { Council of Canadians } \\
\text { Sierra Club }\end{array}$ & $\begin{array}{l}\text { AFL-CIO } \\
\text { United Steel Workers of America } \\
\text { International Longshore and Warehouse } \\
\text { Union } \\
\text { Some Churches }\end{array}$ \\
\hline$\frac{\frac{\text { Formal }}{\text { Transnational }}}{\underline{\text { Organization }}}$ & $\begin{array}{l}\text { Greenpeace } \\
\text { Friends of the Earth } \\
\text { International Forum on Globalization } \\
\text { Third World Network } \\
\text { Peoples Global Action } \\
50 \text { Years is Enough Network } \\
\text { Women 's Environment \& } \\
\quad \text { Development Org. }\end{array}$ & $\begin{array}{l}\text { International Confederation of } \\
\text { Free Trade Unions } \\
\text { European Farmers Union }\end{array}$ \\
\hline
\end{tabular}

*This list is illustrative, not comprehensive. The organizing scheme draws from McCarthy's (1996) distinction between social movement structures, which are explicitly designed to promote social change goals, and "non-movement" (here "extra-movement) mobilizing structures. The latter group are important components of social movement, but their basic organizational mandates encompass goals beyond those of social movements.

${ }^{1}$ Organizations vary a great deal in their levels of formalization and hierarchy. For instance, Friends of the Earth and Greenpeace have well defined organizational structures and institutional presences while groups like Peoples Global Action resist forming an organizational headquarters, and Reclaim the Streets seeks to sustain a loose, network-like structure relying heavily on electronic communications. 
Table 2: Globalization \& Protest Repertoires:

\section{Selected Anti-World Trade Organization Protest Forms}

\begin{tabular}{|c|c|}
\hline Adaptations of Existing Forms & Innovations in Traditional Protest Forms ${ }^{1}$ \\
\hline $\begin{array}{l}\text { Education \& Mobilization } \\
\text { *Cultivating organizations and "affinity groups" } \\
\text { * Public demonstrations at global site } \\
\text { * Teach-ins and speaker forums } \\
\text { * Coordinated "N30" protests around the globe } \\
\text { * Polity-bridging-- Local MAI-Free Zones } \\
\text { *Nonviolence training/ Medic training }\end{array}$ & $\begin{array}{l}\text { Organization/ Mobilization Actions } \\
* \text { Transnational organization } \\
* \text { Producing NGO Newspaper at global } \\
\text { conferences }\end{array}$ \\
\hline $\begin{array}{l}\text { Framing \& Symbolic Mobilization } \\
\text { *Press Center/ Press Conferences for mainstream media } \\
\text { * Global witnessing / Transcontinental Caravan } \\
\text { *Satirical newspaper wraps } \\
\text { * Dramaturgy } \\
\quad \text {-Street theater \& puppets } \\
\text {-Greenpeace's condom drop } \\
\text {-Banner hangs } \\
\text { *Symbolic protests: } \\
\quad \text { Boston WTeaO Party } \\
\quad \text { Bové's Roquefort resistance } \\
\text { Disruption } \\
\text { * Blockade of international conference site } \\
\text { *Civil disobedience } \\
\text { *Legal observers } \\
\text { *Vandalism against corporate sites }\end{array}$ & $\begin{array}{l}\text { Electronic Activism }^{2} \\
* \text { Information exchange: Internet, list serve } \\
\text { *Independent Media Center } \\
* \text { Rapid response action networks } \\
* \text { Virtual sit-in } \\
* \text { Mirror Web sites } \\
* \text { E-mail and fax jams }\end{array}$ \\
\hline
\end{tabular}

${ }^{1}$ These activities are "innovative" in that they have been introduced to social movement repertoires more recently, although some have been used to some degree for many decades. Most of these forms had been used frequently prior to the protests in Seattle by actors targeting global institutions.

${ }^{2}$ For details on these activities, see "Electronic Civil Disobedience" Car Busters Winter 2000, vol. 1 No. 7, p. 22-3 (www.antenna.nl/ayfa/cb), "Fax Off, Bastards" Car Busters Winter 2000, vol. 1 No. 7, p. 23. Seattle Times 11/30/99 P.A1. 


\section{References}

Aaronson, Susan. Forthcoming. Redefining the Terms of Trade.

Ackerman, Seth. 2000. "Prattle in Seattle: Media Coverage Misrepresented Protests." Pp. 59-66 in

Globalize This! The Battle Against the World Trade Organization and Corporate Rule, edited by Kevin Danaher and Roger Burbach. Monroe, Maine: Common Courage Press.

Atwood, David. 1997. "Mobilizing Around the United Nations Special Session on Disarmament." Pp. 141-158 in Transnational Social Movements and Global Politics: Solidarity Beyond the State, edited by J. Smith, C. Chatfield, and R. Pagnucco. Syracuse, NY: Syracuse University Press.

Audley, John J. 1997. Green Politics and Global Trade: NAFTA and the Future of Environmental Politics. Washington D.C.: Georgetown University Press.

Ayres, Jeffrey M. 1998. Defying Conventional Wisdom: Political Movements and Popular Contention Against North American Free Trade. Toronto: University of Toronto Press.

Ayres, Jeffrey M. $1999 . \quad$ Annals

Barlow, Maude and Tony Clarke. 1998. The Multilateral Agreement on Investment and the Threat to American Freedom. Washington D.C.: Public Citizen's Global Trade Watch.

Canadian Security Intelligence Service. 2000. "Anti-Globalization: A Spreading Phenomenon." Report \#2000/08, Canadian Security Intelligence Service. (August 22). Available at: http://www.csis-scrs.gc.ca/eng/miscdocs/200008e.html.

Chatfield, Charles. 1997. "Intergovernmental and Nongovernmental Associations to 1945." in Transnational Social Movements and World Politics: Solidarity Beyond the State, edited by J. Smith, C. Chatfield, and R. Pagnucco. Syracuse, NY: Syracuse University Press.

Clark, Ann Marie, Elisabeth J. Friedman, and Kathryn Hochstetler. 1998. "The Sovereign Limits of Global Civil Society: A Comparison of NGO Participation in UN World Conferences on the Environment, Human Rights, and Women." World Politics 51:1-35.

Cleary, Seamus. 1996. “The World Bank and NGOs.” Pp. 63-97 in The Conscience of the World: The Influence of Non-Governmental Organisations in the UN System, edited by P. Willetts. Washington D.C.: The Brookings Institution.

Finnemore, Martha. 1996. National Interests in International Society. Ithaca, NY: Cornell University Press.

Foster, John. 1999. "Civil Society and Multilateral Theatres.” Pp. 129-195 in Whose World Is It Anyway? Civil Society, the United Nations, and the Multilateral Future, edited by J. W. Foster and A. Anand. Ottawa: United Nations Association of Canada.

Fox, Jonathan and L. David Brown. 1998. The Struggle for Accountability: The World Bank, NGOs, and Grassroots Movements. Cambridge: MIT Press.

Fox, Jonathan. 2000. “Assessing Binational Civil Society Coalitions: Lessons from the Mexico-U.S. 
Experience.” Working Paper Number 26, Chicano/Latino Research Center, University of California, Santa Cruz (April).

Gamson, William A. 1991. "Commitment and Agency in Social Movements." Sociological Forum 6:27-50.

Gerhards, Jürgen and Dieter Rucht. 1992. "Mesomobilization: Organizing and Framing in Two Protest Campaigns in West Germany.” American Journal of Sociology 98: 555-595.

Gillham, Patrick F. and Gary T. Marx. 2000. "Complexity and Irony in Policing and Protesting:

The World Trade Organization in Seattle." Social Justice 27 (2): 212-236.

Institute for International Economics. 1999. "International Economics Policy Issues. " Institute for International Economics, Washington D.C.

Keck, Margaret and Kathryn Sikkink. 1998. Activists Beyond Borders. Ithaca: Cornell University Press. Khor, Martin. 1999. "How the South is Getting a Raw Deal." Pp. 7-53 in Views from the South: The Effects of Globalization and the WTO on Third World Countries. San Francisco: International Forum on Globalization.

Levering, Ralph A. 1997. "Brokering the Law of the Sea Treaty: The Neptune Group." in Transnational Social Movements and Global Politics: Solidarity Beyond the State, edited by

J. Smith, C. Chatfield, and R. Pagnucco. Syracuse, NY: Syracuse University Press.

Levi, Margaret and David Olson. 2000. "Strikes! Past and Present- and the Battle in Seattle."

Politics and Society 28:xxx-xxx.

Lipsky, Micheal. 1968. "Protest as a Political Resource.” American Political Science Review 62:1144-1158.

Democracy." Journal of World Systems Research http://csf.colorado.edu/wsystems/jwsr.html 5:242-262.

Marks, Gary and Doug McAdam. 1996. "Social Movements and the Changing Structure of Political Opportunity in the European Community." Pp. 95-120 in Governance in the European Union, edited by G. Marks, F. W. Scharpf, P. C. Schmitter, and W. Streeck. Thousand Oaks, CA: Sage.

Marullo, Sam, Ron Pagnucco, and Jackie Smith. 1996. "Frame Changes and Social Movement Contraction: U.S. Peace Movement Framing After the Cold War." Sociological Inquiry 66:1-28.

McAdam, Doug. 1988. Freedom Summer. New York: Oxford University Press.

McAdam, Doug, Sidney Tarrow, and Charles Tilly. Forthcoming. Dynamics of Contention. New York: Cambridge University Press.

McCarthy, John D. 1996. "Mobilizing Structures: Constraints and Opportunities in Adopting, Adapting and Inventing." in Political Opportunities, Mobilizing Structures and Framing: Social Movement Dynamics in Cross-National Perspective., edited by D. McAdam, J. McCarthy, and M. Zald. New York, NY: Cambridge University Press.

Meyer, John W., John Boli, George M. Thomas, and Francisco O. Ramirez. 1997. "World Society 
and the Nation-State.” American Journal of Sociology 103:144-181.

Naím, Moisés. 2000. “Foreign Policy Interview: Lori's War.” Foreign Policy 118:28-55.

Njeh $\leftarrow$, Njoki Njoroge. 2000. "Building the Movement: Johannesburg, Seattle, and Beyond." Economic Justice News 2:2,18.

O'Brien, Robert, Anne Marie Goetz, Jan Aard Scholte, and Marc Williams. 2000. Contesting Global Governance: Multilateral Economic Institutions and Global Social Movements. New York: Cambridge University Press.

PGA. 2000. "The Accelerating History of PGA” Worldwide Resistance Roundup Inspired by Peoples Global Action Bulletin 5, February (UK Edition). On file with the author.

Rich, Bruch. 1994. Mortgaging the Earth: The World Bank, Environmental Impoverishment and the Crisis of Development Boston: Beacon Press.

Rose, Fred. 2000. Coalitions Across the Class Divide: Lessons from the Labor, Peace, and Environmental Movements. Ithaca: Cornell University Press.

Scholte, Jan Aart. 2000. "Cautionary Reflections on Seattle” Millennium: Journal of International Studies 29:115-121.

Shoch, James. 2000. "Contesting Globalization: Organized Labor, NAFTA, and the 1997 and 1998 Fast-Track Fights." Politics and Society 28:119-150.

Sikkink, Kathryn and Jackie Smith. Forthcoming. "Infrastructures for Change: Transnational Organizations, 1953-1993." in Restructuring World Politics: The Power of Transnational Agency and Norms, edited by S. Khagram, J. Riker, and K. Sikkink.

Smith, Christian 1994. Resisting Reagan. Chicago: University of Chicago Press.

Smith, Christian. 1996. "Correcting a Curious Neglect, or Bringing Religion Back In.” Pp. 1-25 in Disruptive Religion: The Force of Faith in Social Movement Activism, edited by C. Smith. New York: Routledge.

Smith, Jackie. 1995. "Transnational Political Processes and the Human Rights Movement." Pp. 185-220 in Research in Social Movements, Conflict and Change, vol. 18, edited by L. Kriesberg, M. Dobkowski, and I. Walliman. Greenwood CT: JAI.

Smith, Jackie. 1997. "Characteristics of the Modern Transnational Social Movement Sector." Pp. $42-58$ in Transnational Social Movements and World Politics: Solidarity Beyond the State, edited by J. Smith, C. Chatfield, and R. Pagnucco. Syracuse, NY: Syracuse University Press.

Smith, Jackie. 2000. "Globalization and Political Contention: Brokering Roles of Transnational Social Movement Organizations." Paper presented at German Political Science Association Meeting. Halle, Germany.

Smith, Jackie, Charles Chatfield, and Ron Pagnucco. 1997. Transnational Social Movements and Global Politics: Solidarity Beyond the State. Syracuse, NY: Syracuse University Press.

Smith, Jackie, Ron Pagnucco, and Charles Chatfield. 1997. "Transnational Social Movements and Global Politics: A Theoretical Framework.” in Transnational Social Movements and Global 
Politics: Solidarity Beyond the State, edited by J. Smith, C. Chatfield, and R. Pagnucco. Syracuse NY: Syracuse University Press.

Smith, Jackie, Ron Pagnucco, and George Lopez. 1998. "Globalizing Human Rights: Report on a

Survey of Transnational Human Rights NGOs.” Human Rights Quarterly 20:379-412.

Stevenson, Richard W. 2000. "Trade Support is Dwindling, Fed Chief Says: Policy Makers Note

Globalization Protests.” Pp. C1, C14 in New York Times.

Stiglitz, Joseph. 2000. "What I Learned at the World Economic Crisis." The Insider .

Tarrow, Sidney. 2001. "Transnational Politics: Contention and Institutions in International Politics." Annual Review of Political Science 4:1-20.

Tilly, Charles. 1984. "Social Movements and National Politics.” Pp. 297-317 in Statemaking and

Social Movements: Essays in History and Theory, edited by C. Bright and S. Harding.

Ann Arbor: University of Michigan Press.

UNDP (United Nations Development Programme) Annual. Human Development Report. New York: Oxford University Press.

Vidal, John. 1999. “The Trade Talks Collapse: Real Battle for Seattle.” P. 20 in The Observer. London. December 5.

Walton, John and Dave Seddon. 1994. Free Markets and Food Riots: The Politics of Global Adjustment. Cambridge, MA: Blackwell.

Wallach, Lori and Michelle Sforza. 1999. Whose Trade Organization?: Corporate Globalization and the Erosion of Democracy. Washington D.C.: Public Citizen.

Willetts, Peter. 1996. The Conscience of the World: The Influence of NGOs in the United Nations System. London: C. Hurst.

Zoll, Dan. 1999. "Developing Nations Complain of Being Shut Out of Ministerial Planning Process.” Pp. 1, 8 in World Trade Observer. www.worldtradeobserver.org. 